\title{
_logi melléklet
}

\section{Szankcionálható-e az árbevételre vetített progresszív adó?*}

DEÁK DÁNIEL

A dolgozat háttérmagyarázatot ad az árbevételre vetitett progresszív tagállami adózást uniós jogi nézöpontból megitélő jogesetekhez. A helyi politikának fontos eszköze lett az ágazati különadók bevezetése, ami részben jelentös költségvetési bevételt jelent, de még fontosabb szempont a gyengébb, de az állam által patronált hazai versenytársak helyzetbe hozása. E politika felveti természetesen a tiltott állami támogatás gyanúját, de úgy tünik, hogy most a vita számos, az érintett tagállamok számára kedvezö európai bírósági döntés után eldölni látszik. E döntések az érintett országok szakértöi köreiben általános meglepetést keltettek, mert az itt élök számára nyilvánvaló a burkolt, de valós állami támogatás. Úgy tünik, a meglévö uniós eszköztár

* A dolgozat az alábbi európai bírósági döntésekhez ad háttérmagyarázatot: a kiskereskedelmi adó tárgyában a Törvényszék T-836/16., T-624/17. Bizottság kontra Lengyel Köztársaság sz. egyesített ügyekben 2019. május 16-án született ítélete (jelenleg a Bizottság fellebbezése nyomán a másodfokú eljárás C-562/19. P. sz. alatt folyamatban); a reklámadó tárgyában a Törvényszék T-20/17. Bizottság kontra Magyarország ügyben 2019. június 27-én meghozott ítélete (jelenleg a Bizottság fellebbezése nyomán a másodfokú eljárás C-596/19. P. sz. alatt folyamatban); a távközlési adó kapcsán a Bíróság (Nagytanács) által a C-75/18. Vodafone-ügyben 2020. március 3-án meghozott ítélete; a bolti kiskereskedelmi adó kapcsán a Bíróság (Nagytanács) által a C-323/18. Tesco-ügyben 2020. március 3-án meghozott ítélete; az adóhatósági eljárási jogok (reklámadó) tárgyában a Bíróság (Nagytanács) által a C-482/18. Google-ügyben 2020. március 3-án meghozott ítélete; a dohányipari egészségügyi hozzájárulás és az élelmiszerlánc-felügyeleti dij felfüggesztése tárgyában a Törvényszék T-554/15., T-555/15. Bizottság kontra Magyarország sz. egyesített ügyekben meghozott ítélete, valamint ugyanebben az ügyben Magyarország fellebbezése nyomán a Bíróság C- 456/18. P. (jogerős) sz. 2020. június 4-én meghozott ítélete. A jogesetekhez összefoglalóan lásd a mellékletet.

A kézirat első változata 2020. augusztus 20-án érkezett szerkesztőségünkbe.

https://doi.org/10.47630/KULG.2020.64.9-10.89

Deák Dániel, kutatóprofesszor. Budapesti Corvinus Egyetem, Gazdaság- és Közpolitika Intézet, Összehasonlító és Intézményi Gazdaságtan Tanszék. E-mail: daniel.deak@uni-corvinus.hu. 
elégtelennek bizonyult az ágazati különadók esetében a tiltott állami támogatási politika megállitására. A jog egyértelmüséget kíván meg, ezért olyan praktikákat, mint amilyeneket a nyilvánvalóan célzott ágazati különadók esetében is megfigyelhetünk, aligha lehet leleplezni, ilyen értelemben pedig a burokban élö uniós bírói fórum képviselöje sem hibáztatható.*

Journal of Economic Literature (JEL) kódok: F02, H27, K34.

Kulcsszavak: árbetételre vetített adóprogresszió, vélelmezett nyereségadó, kiskereskedelmi adó, reklámadó, távközlési adó, adóhatósági eljárási jogok, uniós szkepticizmus.

Abstract

Is the progressive turnover tax to be sanctioned?

DÁNIEL DEÁK

The article provides an explanation for the case law on the EU Member States' progressive taxation, levied on turnover in the light of the harmonised EU law. The introduction of special sectoral taxes has become an important measure of local tax policies, which in part generate significant budget revenues but, more importantly, they are also designed to protect the position of weaker domestic competitors. This policy raises the suspicion of illegal state aid, but now this debate seems to be settled after a number of judgements decided by the Court of Justice of the EU in favour of the Member States.

These judgments came as a general surprise to experts in the Member States concerned because the covert, yet effective state aid provided to domestic competitors seems obvious for those who live here. However, the EU's existing 'legal toolbox' has proved to be insufficient to stop the Member States from following a policy of illegal state aid. The law requires clarity, and the practices that can be observed in the case of the apparently selective sectoral taxes can be hardly disguised. In this sense, even the judicial bodies of the EU, living to some extent in an ivory tower, cannot be blamed either.

Journal of Economic Literature (JEL) codes: F02, H27, K34.

Keywords: progressive turnover tax, presumptive profit tax, turnover tax on retail sector, turnover tax on advertisement, turnover tax on telecommunication operators, procedural rights of the tax authorities, scepticism of the Union. 


\section{Előzmények}

$\mathrm{Az}$ árbevételre kivetett progresszív adók ágazati különadók képében jelentek meg egy évtizede Magyarországon és azután néhány más kelet-európai országban is. Megítélésük sok bizonytalanságot rejt magában és komoly bírálatot váltott ki. Az Orbán-kormányok - lévén, hogy Magyarország viszonylag szegény ország ugyanúgy rászorultak, mint elődeik arra, hogy a jövedelemadók helyett a hangsúlyt a fogyasztási adókra helyezzék. Ennek szociális kihatása igen terhes, hiszen a társadalmi egyenlötlenségek csillapításának klasszikus eszköze a jövedelemadó lenne.

A kelet-európai kormányok - mivel tőkében és fejlett technológiában szegények - rászorulnak az erőteljes tőke- és technológiaimportra, és ehhez a szükséglethez igazítják gazdaságpolitikájukat. Az adópolitikát illetően érdekeltek az adóversenyben, ami sokáig különleges gazdasági övezetek bevezetését és fenntartását jelentette, amit azonban az európai integráció lehetetlenné tett. A tökevonzás érdekében kulcskérdés a jövedelemadók általános csökkentése és nagy kedvezmények biztosítása a külföldi befektetőnek, ami korlátok között bár, de az Unióban is fenntartható.

Az Orbán-kormányok gazdaságpolitikájának sajátossága, hogy a 2008-as globális pénzügyi válságot követően az iparfejlesztő intézkedések kerültek előtérbe, és egyúttal az állam fokozott mértékben törekszik kiterjeszteni befolyását a gazdaságra. Ennek súlyos következménye a piaci átláthatóság minimálisra szorítása. Amíg ez csak az országhatárokon belül történik, az Uniónak nincs köze hozzá, amint azonban e politika az uniós kereskedelmet is érinti, uniós jogi problémák merülnek fel.

A szolgáltató szektorokban a magyar állam megerősítette pozícióit, ha szükséges volt, visszavásárolva a külföldi befektetőktől például bankokat és energiaszolgáltatókat. Az iparfejlesztés viszont az országot az összeszerelö üzemek befogadó terepévé tette. Ezért egyebek mellett súlyos árat kellett fizetni a szociális szférában, a munkaügyi szabályozásban, a közoktatásban és az egészségügyben, és ezek az ágazatok lassú sorvadásnak indultak, vagy stagnálnak. A kormányzat, amit tudott, központosított, aminek eredménye lett például a helyi önkormányzatok leépülése.

Az államilag támogatott hazai gazdaság versenyképességének megőrzése és a sokkal fejlettebb és nagyobb külföldi szolgáltatókkal szembeni lehetőség szerinti védelme kiemelt kormányzati céllá vált. Ez annál is inkább szükségesnek látszott, mert az Unióba való belépéskor a kevésbé fejlett új tagállamok megnyitották a korábban adminisztratív eszközökkel jobban védett piacaikat, aminek az eredménye a termékek és szolgáltatások Nyugat-Európából áramló masszív dömpingje lett, s ez immár hagyományos vámvédelmi intézkedések hiányában nem dömpingnek, hanem 
szabad versenynek látszik, ami pedig a belső piac lelke. ${ }^{1}$ A helyi politikának fontos eszköze lett az ágazati különadók bevezetése, ami részben jelentős költségvetési bevételt jelent, de még fontosabb szempont a gyengébb, de az állam által patronált hazai versenytársak helyzetbe hozása.

E politika felveti természetesen a tiltott állami támogatás gyanúját, de úgy tünik, hogy most a vita számos európai bírósági döntés után eldőlni látszik. E döntések az érintett országok szakértői köreiben általános meglepetést keltettek, mert az itt élők számára nyilvánvaló a burkolt, de valós állami támogatás. Erre könnyü következtetni például olyan jelenségekből, mint a kiválasztott hazai szereplők sokirányú kedvezményezése és a szolgáltatásokban aktív külföldi befektetők helyzetének megnehezítése állami beavatkozás révén.

Korábban kétféle területen próbálta az Unió adópolitikai eszközökkel visszaszorítani a versenyszabadság tagállami korlátozását, amiben lényegében sikert is ért el, szoros összefüggésben azzal, hogy mindkét terület a jövedelemadózást érinti. Az egyik területen, az ellenőrzött külföldi társaságok (EKT) adójogi helyzetének megítélése kérdésében folyó küzdelmet a kelet-európai perifériaországok elveszíteni látszanak. Itt az áttörést a Cadbury-ítélet ${ }^{2}$ jelentette, amelyet azután az Európai Unió Bíróságának (EUB) további döntései is megerősítettek. Világossá vált, hogy a gazdag tőkeküldő államok képesek az EKT-politika segítségével védekezni az adóversennyel szemben, mert bár az EKT általában véve a letelepedési és tőkeszabadság nem megengedhető korlátozása, a teljesen mesterséges helyzetek kialakítása ellen mégis felléphetnek a tőkeküldő államok, ami összeegyeztethetőnek bizonyult az uniós joggal.

A másik eszköz az anya- és leányvállalati irányelv, ${ }^{3}$ amelyre támaszkodva ítéletek mondták $\mathrm{ki}^{4}$ azt, hogy a társasági adóba rejtett osztalékadó nem összeegyeztethető az irányelvvel. E korlátokat felismerve vezette be az Orbán-kormány az ágazati különadókat árbevételre vetített progresszív adómértékkel, ami egyúttal populista politikájának elfogadottságát is erősítette. A Kelet-Európa számára hátrányos versenyszabadság korlátozása érdekében így egyfelől cél a nem kívánatos külföldi befektetők - például pénzügyi vállalkozások, energiaszolgáltatók és élelmi-

${ }^{1}$ A globális szinten kibontakozó egyenlötlenség és privilegizáltság mögött meghúzódó törvényszerüségek az EU-ban is hatnak. A centrumban lévő vállalatok a magasabb technológiai színvonal, termelékenység és hatékonyság miatt képesek dömpingre, ami a periférián piaci előnyt jelent az ottani vállalatok kínálatával szemben, az intézményesen liberalizált kereskedelem miatt azonban kiegyenlítő illetéket nem lehet alkalmazni. Lásd Kukovec 2016:52.

${ }^{2}$ L C-196/04. Cadbury Schweppes és Cadbury Schweppes Overseas, ECLICLI:EU:C:2006:544.

${ }^{3}$ Lásd a többször módosított Tanács 2011/96/EU irányelvet HL „L” 345 (2011. 12. 29.).

${ }^{4}$ Lásd például: C-294/99. Athinaïki Zythopoiia, ECLI:EU:C:2000:505. 
szer-kiskereskedők - elriasztása attól, hogy a magyarországi szolgáltatószektorban tevékenykedjenek. Másfelől viszont a kiválasztott iparvállalatok kedvezményezése tovább folyik, például a névleges és tényleges társasági adómérték alacsonyan tartásával (a névleges adómérték Magyarországon jelenleg 9 százalék), és főként az olcsó és megfegyelmezett munkaerő biztosításával. Úgy tűnik, a meglévő uniós eszköztár elégtelennek bizonyult a tiltott állami támogatási politika megállítására.

\section{Az árbevételre vetített adóprogresszió problémája}

Az ágazati különadók közgazdasági és jogi szempontból is problematikusak. Közgazdasági nézőpontból tartani kell attól, hogy - mivel elkülönült ágazati szabályozóként működnek - korlátozzák a piac átláthatóságát és a piaci hozzáférhetőséget. További jellemzőjük, hogy ugyan az állam az adót árbevételre veti ki, ezzel együtt mégis progresszív adómértékeket alkalmaz. Itt felmerülhet a hátrányos megkülönböztetés jogi problémája. Progresszív adómértékek bevezetése önmagában még nem vezet az adóalanyok közötti önkényes megkülönböztetéshez, ami azonban igazolandó. Az igazolhatóságnak nyilvánvaló terepe a jövedelemadó, az igazolásnak pedig kézenfekvő eszköze a jogszabályi megkülönböztetés hozzáigazítása az adózók fizetőképességéhez. Az adóprogresszió alkalmazásának célja a disztributív igazságosság érvényesítése: a különböző teherviselő képességủeket differenciált adójogi elbánásban kell részesíteni. A „Parteispende”-ítélet azt mondja ki immár klasszikus módon, hogy az egymástól különböző adózók egységes adójogi kezelése ugyanúgy megsérti az adóegyenlöség elvét, mintha az adójog az egymással összehasonlítható helyzetben lévő adózók között tenne különbséget. ${ }^{5}$

Más a helyzet a progresszív adómértékek alkalmazásával a forgalmi adózásban. Itt ugyanis a megkülönböztetés igazolása a fizetőképességgel erősen kétséges, az árbevétel és a fizetőképesség közötti viszony ugyanis korántsem egyértelmü. A lehetséges igazolhatóság indoka lehet externália felmerülése, és valóban, ilyen esetekben az adó gyakran represszív, szinte büntetőjelleget ölt. Ez a helyzet például az alkoholfogyasztás vagy környezetszennyező tevékenység megadóztatása esetében.

Ilyenkor a jogalkotói megfogalmazásból és a hatósági jogalkalmazásból világosan ki kell derülnie a jogalkotói célnak. Árbevételre kivetett progresszív adó csak kivételes lehet, egy nem kivételes helyzetben azonban nincs indok különadóztatásra.

${ }^{5}$ BVerfGE 8, 51 - 1, Urteil vom 24.06 .1958 (Parteispenden-Urteil), B.III.2. Letölthető: https:// www.servat.unibe.ch/dfr/bv008051.html. 
Másképpen megfogalmazva, nincs ok eltérni az árbevétellel arányos tiszta adóztatástól, amikor az egységes adómérték alkalmazása a jó megoldás. A nem kivételes helyzetben az adópolitikai megfontolás nem azt diktálja, hogy eltérjünk az arányos adózástól.

Nyilvánvalóan a progresszivitás ellen szól, hogy a magasabb adómértékek hatálya alá nagyvállalatok esnek, amelyek joggal panaszkodnak hátrányos megkülönböztetés miatt, ami csak akkor lenne kiküszöbölhető, ha az adófizetés az adózók teherviselő képességéhez igazodna, a nagyobb árbevételből viszont egyáltalán nem következik nagyobb nyereség. A közvetett adók a fogyasztók és nem az adóalanyok fizetőképességére hatnak, ezért ezen az alapon a magasabb árbevétel nem indokolja a szigorúbb adóztatást. Más kérdés, hogy mivel egy-egy ágazatot terhelő speciális adókról van szó, nehéz az adónemeket kategorizálni, és vannak, akik vitatják a kérdéses adók közvetettadó-jellegét. Ez utóbbi probléma már az olasz IRAP és a magyar helyi iparüzési adó esetében is felmerült. ${ }^{6}$

Az Európai Bizottság 2018. március 21-én szintén előterjesztett egy irányelvjavaslatot ${ }^{7}$ egy árbevételre kivetett digitális szolgáltatási adó tárgyában. Az adónak ugyan 3 százalékos egységes kulcsa lenne, annyiban azonban emlékeztet a progreszszivitásra, hogy lényegében csak magas árbevételi küszöbbel rendelkező globális vállalatok esnének adóztatás hatálya alá, amit a Bizottság azzal indokol, hogy a digitális szolgáltatások bevételének adózatlanul hagyása lényegében externália, mivel a fogyasztók, akikből a digitális szolgáltatók élnek, a forrásországban találhatók, amely azonban mégsem adóztathat a nemzetközi adózás szokásos kapcsolóelveit figyelembe véve (ehhez ugyanis arra lenne szükség, hogy a szolgáltató állandó telephelyet létesítsen abban az országban, ahol a fogyasztó van letelepedve). Mivel a javasolt adót az árbevételre vethetik ki, az adóztatás eleve kívül marad a jövedelemadózás tárgykörén, bár lényegében az elmaradt jövedelemadó-bevétel pótlására szolgál.

Az ágazati adókkal kapcsolatban uniós színtéren közvetlenül a tiltott állami támogatás problémája merül fel, ennek központi kérdése pedig az, hogy miként határozható meg az összehasonlítás alapja, vagyis egy ún. referenciakeret, amelyhez képest eldönthető, hogy vajon szelektívnek minősíthető-e a vizsgált adójogi intézkedés. Némi leegyszerüsítéssel azt lehet mondani, hogy vita áll fenn az európai ver-

${ }^{6}$ C-475/03. Banca popolare di Cremona Soc. coop. arl kontra Agenzia Entrate Ufficio Cremona, ECLI:EU:C:2006:629; C-283/06. KÖGÁZ, C-312/06. OTP Garancia Biztosító, sz. egyesített ügyek, ECLI:EU:C:2007:598.

7 Tanácsi irányelvjavaslat az egyes digitális szolgáltatások nyújtásából származó bevételek után fizetendő digitális szolgáltatási adó közös rendszeréről, COM/2018/0148 final - 2018/073 (CNS).

94 JOGI MELLÉKLET • 2020/9-10 
senyhatóságként is múködő Európai Bizottság és az érintett tagállamok között. Ennek lényege abban áll, hogy milyen az adott ügyben alkalmazandó referenciakeret, vagyis mi a lehetséges alapja a kritikus adó és egy mintaadó összehasonlításának.

Utóbbit az EUB úgy határozta meg, hogy utalt egy ideális helyzetre: ,,[... $n a$ ture or general scheme of this system"8. E szerint nincs gond a vizsgált adóval, ha része ennek a normálisnak tekinthető adórendszernek. A Bizottság abból indult ki, hogy a referenciakeret meghatározásához alapvetően az adóztatás tárgyát szükséges figyelembe venni.

Az EUB alább tárgyalandó ítéleteiben megjelenő érvelés szerint a Bizottság által megállapított referenciakeret fiktív. A valós referenciakeret meghatározásakor ugyanis nem megkerülhető, hogy figyelembe vegyük a törvényhozói célt, amely az árbevételre kivetett progresszív adó esetében a bevétel biztosítása mellett - rejtve vagy kifejezetten - magába foglalhat egy kívánatos redisztribúciót is. Ebből következően a vizsgált adó progresszív mértékeit is el kell ismerni, mint amelyek részei a referenciakeretnek (illetve az eljáró bíróság szóhasználatában: a referenciarendszernek). Ezért az adó összefüggésbe hozható az adózó fizetőképességével, ami igazolhatóvá teszi a megkülönböztetést. Így tehát az adó nem tekinthető szelektívnek. A Bizottság szerint viszont a fizetőképességre való hivatkozás alaptalan, mivel nem fedezhető fel értékelhető összefüggés az árbevételre vetített adóprogresszió és a fizetőképesség között.

Az itt felvetődő kérdések súlyához és bonyolultságához képest többnyire lakonikus rövidségủ ítéletekkel találkozunk, amelyek kategorikusan elutasítják a Bizottság érvelését. Az EU bírói fórumai azonban nem indokolják meg alaposan azt, hogy miért kellene a tagállamok által meghatározott referenciarendszerhez ragaszkodni a Bizottság által felállított referenciarendszer helyett, hanem egyszerün elfogadják a tagállami szabályozási struktúrát úgy, ahogy az van, figyelmen kívül hagyva az árbevételre vetített progresszív adó által kiváltott valós gazdasági hatást. Az „economies of scale" elvére való vérszegény hivatkozás (a nagyobb árbevétel költségmegtakarításhoz és nagyobb nyereséghez segítheti a vállalatot) még nem kínál érdemi magyarázatot arra, hogy ugyan miért tévedett az alkalmazandó jogban a Bizottság (Nicolaides, 2019:236).

${ }^{8}$ E referenciakeretet elöször a 173/73. sz. ügyben alkalmazták, amikor az Olasz Köztársaság családi adókedvezményeket nyújtott a textilipari szektorban aktív vállalkozásoknak. Lásd: 173/73. Olasz Köztársaság kontra az Európai Közösségek Bizottsága, ECLI:EU:C:1974:71, 15. bek. 


\section{Vélelmezett nyereségadó}

Az árbevételre kivetett adó - ha nem is progresszív mértékek alkalmazásával - nyereségadó pótlásaként szokott előfordulni olyan helyzetekben, amikor az adóköteles nyereség megállapítása túl bonyolult vagy az érintett adózónak túl nagy adminisztratív terhet jelent. A nyereségpótló árbevételt terhelö adó tulajdonképpen a nyereségadó „,proxyja”, vélelmezett nyereségadó. Jogosságát gyakran azzal indokolják, hogy az ilyen adó bevezetésére az adóelkerülés elterjedtsége miatt kerülhet sor. Ezt az érvet általában a nemzetközi gyakorlatban is elfogadják, feltéve hogy az adó kellöképpen célzott.

Az árbevételre kivetett adó egy Pigou-adóhoz (Baumol, 1972) hasonlítható. Olyan, mintha a környezetterhelés társadalmi költségeinek pótlására szolgálna, csak az externália ez esetben az adóelkerülés, különösen az olyan határon átnyúló adóelkerülés, amely technikailag nem is tekinthető joggal való visszaélésnek. Csupán esetlegességekből adódik ugyanis, például abból, hogy az adóoptimalizálás lehetősége éppen azért nyílik meg, mert az adózó eléggé nagyméretű piaci szereplő, vagy mert az adózó vállalkozásában különös menedzseri képességeket összpontosított. Ilyenkor az adózó nagyvállalat abban a helyzetben van, hogy választhat nemzeti adórendszerek egyes eszközei között, és kitöltheti azokat a réseket, amelyek abból adódnak, hogy a szuverén államok nem vagy nem elégséges módon hangolják össze egymással adópolitikájukat.

A brit eltérítettnyereség-adó (Diverted Profits Tax - DPT) is vélelmezett nyereségadó. ${ }^{9}$ Ez az adó kétségtelenül a határon átnyúló agresszív adótervezés visszaszorítására irányul, mégpedig a BEPS-projektre $(\mathrm{OECD}, 2013)$ való utalással. Ironikus ugyanakkor a BEPS-re való hivatkozás, egy olyan projektre, amelynek újdonsága az integratív és holisztikus, vagyis nemzeti adórendszereken átívelő megközelítés. Ezzel élesen szembehelyezkedik minden egyoldalú nemzetállami lépés, amelyek végeredményben nem segítik az adóelkerüléssel szembeni védekezést.

Az ilyen típusú adó bevezetésének célja nem csupán adóbevétel elérése, hanem legalább ennyire fontos a társadalmilag károsnak minősített magatartástól való viszszatartás. E különös céllal függ össze, hogy a DPT elkerülhető, ha az adózó bejelentését követően megegyezés születik az adóhatósággal. Ha az adózók elkerülik a büntetőjellegü adók megfizetésének kötelezettségét, kevesebb adót fognak fizetni, de fognak adót fizetni, szemben a korábbi, adókikerülést lehetővé tevő állapotokkal.

9 A 2015-ös költségvetési törvénybe került be, és 2015. április 1-jétől alkalmazandó (HMRC, 2015).

96 JOGI MELLÉKLET • 2020/9-10 
Mivel a magyar és lengyel ágazati különadók árbevételre vetített progresszív adók, jelentősen különböznek a DPT-től és társaiktól, és nem is igazolhatók externáliával.

Felvetődik még a kérdés, hogy vajon egy ágazati különadó közvetett adó-e, közelebbről forgalmi adó-e. Fogyasztásiadó-koncepció érvényesülhet jövedelemadózásnál is, amikor ti. a megtakarításokat nem, vagy alig adóztatják, és az adóztatás súlypontja a közvetlenül fogyasztásra felhasznált jövedelem. Az árbevételből mégis fogalmilag következik, hogy az adózó áthárítja az adót a fogyasztóra, de kétségtelen, hogy az áthárítás nem igazolható olyan egzakt módon, mint a hozzáadott érték adó esetében. Nem tekinthetjük ugyanis bizonyosnak, hogy az adózó a rá kivetett adót tényleg áthárítja.

\section{Lengyel kiskereskedelmi adó}

A T-836/16., T-624/17. Európai Bizottság kontra Lengyel Köztársaság sz. egyesített ügyekben ${ }^{10}$ a Törvényszéknek elsősorban a szelektivitás problémáját kellett megítélnie, törekedvén rámutatni arra, hogy az elmarasztaló bizottsági határozatokban ${ }^{11}$ a vizsgált adónem minősítésében jogi hiba rejlik. A Törvényszék a referenciakeret alkalmazhatóságát illetően a következőképpen ítélte meg az esetet:

- a Bizottság a Törvényszék szerint a megtámadott határozatokban egy olyan „normál” rendszert azonosított, amely vagy hiányos, mivel nem tartalmaz adókulcsot, vagy pedig hipotetikus, mivel egységes adókulcsot tartalmaz, ami téves jogalkalmazásnak minősül (67. bek.);

- maga az adó célja is tartalmazhat jogszerủen az adóteher megosztására vagy hatásának mérséklésére irányuló modulációt (83. bek.).

Az Európai Bizottság 2019. július 2-án fellebbezést nyújtott be a lengyel kiskereskedelmi adó tárgyában a T-836/16., T-624/17. sz. egyesített ügyekben meghozott ítélet ellen. ${ }^{12}$

Kérdésként felvetődik, hogy a referenciakeret megállapítása szempontjából a normál rendszer mintáját milyen forgalmi adó képviselheti, és hogy referenciakeretnek tekinthető-e maga az ágazati adóztatás. Ha a hozzáadottérték-adót (a követ-

10 T-836/16., T-624/17. Európai Bizottság kontra Lengyel Köztársaság sz. egyesített ügyek, ECLI:EU:T:2019:338.

${ }^{11}$ SA.44351. (2016/C) (korábbi 2016/NN) számú állami támogatásra vonatkozó, a kiskereskedelmi ágazatban kivetett lengyel adóról szóló, 2016. szeptember 19-i C(2016) 5596 final bizottsági határozat; SA.44351. (2016/C, korábbi 2016/NN) számú állami támogatásról szóló, az eljárást lezáró 2017. június 30-i (EU) 2018/160 bizottsági határozat, OJ L 29, 2018.02.01. 38. o.

${ }^{12}$ Ezt a Bíróság a C-562/19. P. Európai Bizottság kontra Lengyel Köztársaság számon vette nyilvántartásba. 
kezőkben: héa) vesszük alapul, akkor a forgalomra kivetett progresszív adó eltérés a normál rendszertől. Az eredeti magyar megnevezés a 2013. január 1-jéig hatályban volt bolti kiskereskedelmi adó, távközlési adó és energiaadó tekintetében „,különadó", ami azt sugallja, hogy itt nem a rendszerről, hanem az attól való eltérésről van Szó. ${ }^{13}$

A referenciakeret körülírása nem magától értetődő. Ha nincs referenciakeret, akkor a Bizottság eljárása meglehetősen parttalan, és ezért például a normál adóztatás rendszerébe könnyen beilleszthető akár a progresszív adóztatás is. Ha viszont van, akkor az elemzés kiindulópontja a piaci verseny ideáltípusa, ahol az adóztatással szemben megkívánható a fiskális semlegesség, vagyis az, hogy az adóztatás csak a legindokoltabb esetben térítse el a gazdasági szereplőket eredeti döntési preferenciáiktól.

E tekintetben a progresszív adóztatás nyilvánvalóan anomália, ami már önmagában a normálisnak tekinthető adóztatástól való eltérést jelent. A progresszivitás megítélésének paradoxona az, hogy bár elvileg a disztributív igazságosság érvényesítése progresszív adómértékek alkalmazása révén magasabb rendü, ha szigorúan a piac mint önszabályozó rendszer ideáltípusában gondolkodunk, akkor arányos adóztatásra van szükség. Igaz, az utóbbi csak a disztributív igazságosságnál elvileg alacsonyabb rendủ szétosztó igazságosságot képviseli. ${ }^{14}$

Felmerül az a kérdés, hogy vannak-e tisztán költségvetési célra irányuló adók, és hogy éppen ezek tekinthetők-e normálisnak, vagy hogy adott esetben szükséges-e az adónem természetének megállapításához az esetleges redisztribúciós (és gazdaságösztönző) célkitűzés is. A forgalmat terhelő adók tekintetében pusztán a költségvetési cél látszik, és a fiskális semlegesség érvényesítése alapvető jellemző, viszont kivételek (redisztribúciós vagy más okból) nehezen tűrhetők e téren. A jövedelem- és vagyonadóknál inkább normálisnak tekinthető a redisztribúciós funkció beépítése az adott adónembe.

A különös adócélokban megnyilvánuló különbség elismerése miatt az összehasonlíthatóság lehetősége igen korlátozott, ez esetben viszont szinte lehetetlen a szelektivitás megállapítása. Az adó különös céljának kiemelése a nemzetállami joghatósághoz kötött formalizmus alkalmazásának a következménye, miközben az adott adónem által kiváltott, határon átnyúló gazdasági hatások figyelmen kívül maradnak, így pedig az uniós versenytorzító hatás sem állapítható meg. A jogi formalizmus lényegében kiüresíti az összehasonlíthatóság kritériumát, ennek következtében

13 Vö.: 2010. évi XCIV. törvény az egyes ágazatokat terhelő különadóról.

14 Aristotle (2009:82-88), Aquinas [1920], ST II. II. 61. 1-2. 
pedig megnyílik az út bármely moduláció széles körủ tagállami alkalmazhatósága elött.

Ha a szelektivitás nem, vagy csak nagyon nehezen lenne megállapítható, akkor még nyitva marad az a lehetőség, hogy a különös célt követő adók alkalmazása miatt hátrányos megkülönböztetés és ezáltal valamely alapvető uniós szabadság nem igazolható korlátozása legyen megállapítható (Rossi-Maccanico, 2013; Smit, 2016). Ebben az összefüggéskörben továbbá akár a WTO-szabályok betarthatóságának kérdése is felmerülhet (Ehlermann \& Goyette, 2006; Rossi-Maccanico, 2004:239-240), így különösen az állami támogatás, valamint a határon átnyúló diszkriminatív és protektív adóztatás tilalma. Nem kizárt kettős adóztatási egyezmények érintettsége sem, különösen a diszkriminációtilalomról szóló szabályaik vonatkozásában. ${ }^{15}$

\section{Kapcsolódó jogesetek}

A British Aggregates-ügyben a tagállam elismeri, hogy környezetvédelmi okok miatt szelektál egyes építőanyagok között, és ennek megfelelően előnyös adójogi elbánásban részesíti a preferált anyaggal végzett üzleti tevékenységet. Ennek gazdasági hatása versenytorzítás, amit az EUB is tiltott állami támogatásnak bélyegzett. ${ }^{16}$ A versenypiaci szempont tehát ebben az esetben felülírta a környezetvédelmi célt. Az ágazati különadó esetében a tagállam nyíltan nem alkalmaz szelekciót, amit a törvény ennek megfelelően nem is tükröz, de a valóságos hatás mégis szelekció lehet.

A gibraltári „offshore” vállalkozások adóparadicsomi helyzetéből adódó tiltott állami támogatás első megközelítésben a szabályozó rendszerből még nem adódik. A vonatkozó törvény által bevezetett rendszert a munkáltatók száma és az üzleti célú ingatlanok használata - mint kizárólagos adótárgyak - alapján kivetett adónemek együttes alkalmazása jellemzi, és ehhez járul a nyereségességre vonatkozó feltétel, a nyereség 15 százalékában meghatározott felső adókorláttal. A rendszer megfelelő adótárgy hiányában elkerüli az „offshore” társaságok adóztatását, mivel ezek nem rendelkeznek munkavállalóval, és nem használnak üzleti célú ingatlant sem.

${ }_{15}$ Az Alkotmánybíróság megvizsgálta az Írország-Magyarország kettős adóztatási egyezményt (Dublin, 1995. április 25.) a Google eljárási jogokat reklamáló beadványa tükrében, és többségi döntéssel azt állapította meg, hogy adóhatósági eljárási jogi tekintetben összehasonlíthatóság hiányában a hátrányos megkülönböztetés problémája nem vetődhet fel. Lásd: 31/2017. (XII. 6.) AB határozat a reklámadóról szóló 2014. évi XXII. törvény 7/B. §-a és 7/D. §-a nemzetközi szerződésbe ütközésének megállapítására és megsemmisítésére irányuló bírói kezdeményezések elutasításáról, $A B H 708$.

${ }^{16}$ C-487/06 P. British Aggregates Association kontra Európai Bizottság, ECLI:EU:C:2008:757. 85. bek. 
Az EUB a Gibraltár-ügyben kimondott ítélete szerint „,Az Elsőfokú Bíróság által elfogadott megközelités, amely kizárólag az adóreform-tervezet által alkalmazott szabályozási módszer figyelembevételén alapul, nem teszi lehetövé a kérdéses adóintézkedés hatásainak vizsgálatát, és eleve kizárja annak a lehetöségét, hogy az "offshore" társaságok megadóztatásának hiányát »szelektív előnynek« lehessen minösiteni." 17 Pontosan ez a helyzet a magyar és lengyel ágazati különadók esetében is: ha csupán a jogszabályban olvasható progresszív adóztatást nézzük, nem tárhatjuk fel a kérdéses adóintézkedés hatását.

A katalán parlament 2000. december 29-i 16/2000. sz. törvénye a nagy kereskedelmi létesítményekre kivetett adóról (IGEC) szól. ${ }^{18}$ A törvény 2. cikkéből megtudható, hogy az adó a nagy kereskedelmi létesítmények kivételes gazdasági kapacitását terheli, amely létesítmények a nagy eladóterükből adódóan erőfölényhez juthatnak, és negatív hatásokat fejthetnek ki a területre és a környezetre, amely hatások költségeit e létesítmények nem viselik. A jogvita tárgyát képező adótörvény mentességeket és kedvezményeket is biztosít. Ezek igénybevétele függ a kereskedelmi forgalmazási profiltól (vagyis attól, hogy milyen meghatározott termékeket forgalmaznak a kiskereskedelmi vállalkozások), továbbá attól is, hogy az érintett vállalkozások milyen jogi formában müködnek.

Az EU Bírósága megállapította:

- , ,...] noha az eladóterületre vonatkozó adózási kritérium nem olyan kritérium, amely formálisan eltérne egy adott jogi referenciakerettöl, e kritérium azzal a hatással jár, hogy kizárja ezen adó hatálya alól a $2500 \mathrm{~m}^{2}$ alatti eladóterü kereskedelmi létesítményeket." (46. bek.); továbbá

- bár a vizsgált adó a hivatkozott törvényszövegböl következően objektív kritériumokon nyugszik, ,[...] az EUMSZ 107. cikk (1) bekezdése az állami beavatkozásokat hatásaik alapján, az alkalmazott módszerektöl függetlenül határozza meg...” (47. bek.);

- „Ennélfogva nem lehet a priori kizárni, hogy egy ilyen kritérium gyakorlatilag lehetövé teszi »bizonyos vállalkozásoknak vagy bizonyos áruk termelésének elönyben részesitését az EUMSZ 107. cikk (1) bekezdése értelmében, azáltal hogy enyhíti terheiket azon más vállalkozások terheihez képest, amelyek az alapügyben szóban forgó adónak alá vannak vetve.” (48. bek.)

17 106/09. P. és C-107/09. P. Európai Bizottság és Spanyolország kontra Government of Gibraltar és Egyesült Királyság sz. egyesített ügyek, ECLI:EU:C:2011:732. 88. bek.

${ }^{18}$ Lásd: C-233/16. Asociación Nacional de Grandes Empresas de Distribución (ANGED) kontra Generalitat de Catalunya, ECLI:EU:C:2018:280. 6. bek. 
Az EUB az állami támogatás jogszerüségéről szóló vitában a következőképpen foglal állást: „,...] nem vitatható, hogy a kereskedelmi létesitmények környezeti hatása nagymértékben függ e létesitmények méretétöl. Minél nagyobb ugyanis az eladótér, annál nagyobb a vevöforgalom, ami nagyobb környezetszennyezésben nyilvánul meg. Ebböl következik, hogy az eladótérre vonatkozó küszöbre alapitott olyan kritérium, mint amelyet az alapügyben szóban forgó nemzeti jogszabály vesz figyelembe annak érdekében, hogy különbséget tegyen a vállalkozások között aszerint, hogy az általuk a környezetre gyakorolt hatás nagyobb vagy kisebb, a követett célkitüzésekkel koherens.” (53. bek.). A fentiekből egyenesen adódik az EU Bíróságának következtetése: „E körülmények között az adóalanyiságnak az eladótérre alapitott olyan kritériuma, mint amelyröl az alapügyben szó van, a létesitmények olyan kategóriái közötti különbségtételhez vezet, amelyek az e kritériumot megállapitó jogszabály által követett célkitüzésekre tekintettel nincsenek összehasonlitható helyzetben." (55. bek.)

Míg a vállalkozás önmagában vett méretét (pontosabban az eladótér méretét) figyelembe vevő adótörvénynek nem tudható be tiltott állami támogatás, ezzel szemben a vállalkozások jogi formája közötti különbségtétel már kifogásolható, és gazdasági hatását tekintve alkalmas arra, hogy tiltott állami támogatás jöjjön létre (61. bek.). Ugyanakkor az eladótér méretétől függő fizetési kötelezettség kérdését a jogesetből kitűnően a Bizottság még vizsgálhatja, 2014. november 28-i bizottsági levelében ugyanis tájékoztatta a spanyol hatóságokat arról, hogy az IGEC állami támogatások nyújtásával járhat, és hogy az adót ezért módosítani kell, vagy el kell törölni. Ebből adódóan a Bizottság megítélése szerint az olyan adórendszerből eredő állami támogatások, mint amelyről az alapügyben szó van, nem minősülhetnek létező támogatásnak.

Az ágazati különadók szempontjából érdekes: az eladótér nagyságából - vagy éppenséggel a progresszív adómértékekből - adódó azon előny, hogy a küszöböt el nem érő üzletek üzemeltetői, illetve az alacsony forgalmat elérő vállalkozások nem (vagy csak kisebb mértékben) esnek adózás hatálya alá, önmagában véve nem tekinthető állami támogatásnak, a tiltott állami támogatás előfordulása mégsem zárható ki. Ebből adódóan szükséges a megkülönböztetés igazolásának a kérdésével is foglalkozni. Megjegyezhető, hogy míg a spanyol regionális adó jól körülírhatóan hivatkozik ellentételezendő externáliára (környezetszennyezés), addig ez ágazati adók esetében hiányzik. 


\section{Magyar reklámadó}

A magyar reklámadó szintén árbevételre kivetett progresszív adó. A T-20/17. Bizottság kontra Magyarország sz. ügyben ${ }^{19}$ tárgyalt reklámadó esetében tudni való még az, hogy a forgalomra vetített progresszív adómértékek alkalmazása mellett azok az adóalanyok, amelyeknek az adózás előtti eredménye a 2013-as évben nulla vagy negatív volt, csökkenthették 2014. évi adóalapjukat az előző évek elhatárolt veszteségének 50 százalékával (4. bek.). Magyarország az adó hatályba lépésének időpontjára visszamenőleges hatállyal módosította a reklámadót anélkül, hogy azt előzetesen bejelentette volna a Bizottságnak. Formálisan megszüntette ugyan az adómértékekben kifejeződő progresszivitást, de lényegét megőrizte azzal, hogy az egységes kulcs mellett egy másik kategória a törvényi küszöbértéket el nem érő vállalkozások adómentessége. ${ }^{20}$

A tiltott állami támogatást szankcionáló Bizottság álláspontja ${ }^{21}$ lényegét tekintve ugyanaz, mint a lengyel kiskereskedelmi adó esetében, az eltéréseket pedig csupán az eltérő tényállási elemek indokolják. A Bizottság a fizetőképesség és a forgalom mérete között nem lát igazolható összefüggést. A fizetőképesség figyelembevétele valóban csak jövedelemadók esetében kézenfekvő. Az árbevételre kivetett adó és a fizetőképesség között azért sem lehet értelmezhető kapcsolat, mert ilyen adó esetében nem lehetséges a költségek figyelembevétele, még ha az adójogilag elismert költségek elszámolása nyereségadózás esetében sem feltétlenül vezet a tényleges nyereség kiszámításához.

A fizetőképesség és az adótárgy kapcsolata továbbá reálisan csak akkor mérhető fel, ha világjövedelmet veszünk alapul, a forgalmi adózás viszont természeténél fogva területi alapú (Szudoczky \& Károlyi, 2020:53). A fizetőképesség közvetett adó esetében amúgy is nem az adófizetésre kötelezett vállalkozás, hanem az áthárított adó terhét viselő fogyasztó fizetőképességére vonatkozik. A fizetőképesség (abilityto-pay) elvét egyébként a magyar Alaptörvény is elismeri a XXX. cikkben, amely

19 T-20/17. Bizottság kontra Magyarország, ECLI:EU:T:2019:448.

${ }^{20}$ Az adó mértéke 2019. július 1. és 2022. december 31. között az adóalap 0 százaléka. E törvényi rendelkezés összefüggésben van azzal, hogy az Európai Unió Törvényszéke a lengyel bolti kiskereskedelmi adóban az állami támogatások uniós jogával összeegyeztethetőnek tartotta az adónem sávosan progresszív mértékrendszerét, azaz azt a mértékrendszert, amely eredetileg a reklámadóban is alkalmazandó volt. A magyar törvényhozó az Európai Unió Bíróságának döntéséig a hatályos, lineáris adómértéket felfüggesztette azáltal, hogy az adó mértékét 0 százalékban határozza meg.

21 A Bizottság Bíróság előtt megtámadott határozatára lásd a Bizottság határozatát (2016. 11. 4.) a Magyarország által a reklámbevétel adózására vonatkozóan végrehajtott SA.39235 (2015/C) (ex 2015/ NN) intézkedéséről [C(2016) 6929 final]. 
teherbíró képességhez igazodó közteherviselésről szól, igaz, a fizetőképesség érvényesülését némiképpen korlátozó formulában rögzítve, miszerint a fizetőképesség, illetve a gazdaságban való részvétel irányadó, sőt a gyermeknevelési költségeket is figyelembe kell venni.

A Törvényszék álláspontja - amely tárgyánál fogva nagyon hasonló a T-836/16., T-624/17. Bizottság kontra Lengyel Köztársaság sz. egyesített ügyekben meghozott ítélethez - a következöben összegezhető:

- a Bizottság a megtámadott határozatokban egy olyan „normál” rendszert azonosított, amely vagy hiányos, mivel nem tartalmaz adókulcsot, vagy pedig hipotetikus, mivel egységes adókulcsot tartalmaz, ami téves jogalkalmazásnak minősül (82. bek., amely igen pontosan megismétli a lengyel kiskereskedelmi adó tárgyában meghozott ítélet 67. bekezdésében foglaltakat);

- a Bizottságnak nem sikerült bizonyítania a megtámadott határozatban azt, hogy a reklámadó progresszív szerkezete miatt szelektív előny, következésképpen pedig állami támogatás áll fenn (111. bek.). ${ }^{22}$

A Bizottság a lengyel kiskereskedelmi adó ügyéhez hasonlóan ugyancsak fellebbezést nyújtott be, lényegében változatlan tartalommal a magyar reklámadó tárgyában 2019. augusztus 6-án a T-20/17. sz. ítélet ellen. ${ }^{23}$

Az ítéletből magából is kitűnik, hogy az RTL Klub az összes adóelőleg-teher 80 százalékát viselte (108. bek.), ami pedig a 2013. évi veszteségek átvitelének a lehetőségét illeti, ezzel csakis az RTL Klub egyetlen komoly vetélytársa, a TV2 élhetett, és ha nincs ez a veszteségelhatárolásra vonatkozó utólagos módosítás (amely csak 2017. június 30-ig volt hatályban), akkor a TV2 is jelentős adófizető lett volna. A TV2 köztudottan erősen kormánypárti, az RTL Klub viszont nem. A konkrét adóteher megoszlásának kérdésétől eltekintve úgy tünik, a kormány voltaképpeni célja a versenyszabadság és a vélemények kinyilvánítására irányuló szabadság korlátozása és a verseny torzítása volt, amihez az adóztatás csak eszköznek bizonyult.

${ }^{22}$ Ezzel szemben egy akadémiai vélemény szerint a reklámadó az árbevételre vetített progresszív adómértékekből adódó szerkezete miatt élesen szelektív és versenytorzító. Lásd erre és az állítás alapos indokolására: Szudoczky \& Károlyi (2020:54).

${ }^{23}$ Ezt az EUB C-596/19. P. Bizottság kontra Magyarország számon vette nyilvántartásba. 


\section{Távközlési adó és bolti kiskereskedelmi adó}

Az esetek súlyát és a megítélhetőség nehézségeit jól érzékelteti, hogy a C-75/18. Vodafone $^{24}$ és a C-323/18. Tesco sz. ${ }^{25}$ ügyekben, sőt az utóbbi jogeset előzményének tekinthető C-385/12. Hervis sz. ügyben ${ }^{26}$ is egyaránt az EUB nagytanácsa járt el. Különösen nehéznek tünik a bolti kiskereskedelmi adó tárgyában a Tesco- és a Hervis-ügyekben meghozott, egymástól különböző ítéletek egymással való kibékítése, bár a két ügyben kétségtelenül vannak egymástól jelentősen eltérő tényállási elemek is. A kibékítés nehézségének kiemelését indokolja az a körülmény is, hogy a Bizottság harmonizációbarát álláspontja egyaránt egységes a Hervis- és Tescoügyekben, továbbá a C-456/18. P. Bizottság kontra Magyarország sz. ügyben. Két olyan masszív nagytanácsi ítélet után, mint amelyek a Vodafone- és Tesco-ügyekben születtek, mégis megfordíthatatlannak látszik az EUB álláspontja - bár még nincs jogerős döntés - a C-562/19. P., Bizottság kontra Lengyel Köztársaság sz. ügyben (2019. május 16.) a lengyel kiskereskedelmi adó tárgyában és a C-596/19. P. Bizottság kontra Magyarország sz. ügyben a magyar reklámadó tárgyában.

A Vodafone- és a Tesco-ügyekben a felperes adózó egyaránt felvetette az állami támogatás problémáját, tekintve hogy versenytorzító körülmény az, hogy a versenytársak jelentős kedvezményben részesülnek, a felperesnek azonban méreténél fogva sokkal nagyobb adóteherrel kell számolnia, de az EUB egyik esetben sem találta a kérdést befogadhatónak. Az adózó ugyanis nem hivatkozhat más adóelőnyére azért, hogy maga szabaduljon az adókötelezettségtől. Elökerült ugyan ezekben az esetekben a letelepedési szabadság megsértésének és ezzel összefüggésben a hátrányos megkülönböztetésnek a kérdése is, de közvetett diszkrimináció még nehezebben látszik kimutathatónak, mint a szelektivitás (Szudoczky \& Károlyi, 2020:66), és így a tiltott állami támogatás kérdése.

Az EUB ítéletének indokolása a következő lényeges megállapításokat tartalmazza:

- az a körülmény, hogy a különadó legnagyobb részét más tagállamok természetes vagy jogi személyeinek tulajdonában álló adóalanyok viselik, nem lehet alkalmas arra, hogy önmagában hátrányos megkülönböztetést valósítson

${ }^{24}$ C-75/18. Vodafone Magyarország Mobil Távközlési Zrt. kontra Nemzeti Adó- és Vámhivatal Fellebbviteli Igazgatósága, ECLI:EU:C:2020:139.

${ }^{25}$ C-323/18. Tesco-Global Áruházak Zrt. kontra Nemzeti Adó- és Vámhivatal Fellebbviteli Igazgatósága, EU:C:2020:140.

${ }^{26}$ C-385/12. Hervis Sport-és Divatkereskedelmi Kft. kontra Nemzeti Adó- és Vámhivatal Közép-dunántúli Regionális Adó Föigazgatósága, EU:C:2014:47. 
meg, ugyanis az adóteher ilyen eloszlására az szolgál magyarázatul, hogy a magyar távközlési, illetve bolti kiskereskedelmi piacon az olyan adózók vannak túlsúlyban, akik e piacon a legmagasabb árbevételt érik el (Vodafone, 52-54. bek., Tesco, 72-74. bek.);

- a jelen ügyek eltérnek a Hervis-ügytől, utóbbiban meghozott ítélet ugyanis az árbevétel erősen progresszív adókulcsok alapján való megadóztatásának és a kapcsolt vállalkozások árbevételének összeszámításával kapcsolatos szabály együttes alkalmazására vonatkozott, ami azt eredményezte, hogy a vállalatcsoportba tartozó adóalanyok adóztatására „fiktív” árbevétel alapján került sor (Vodafone, 55. bek., Tesco, 75. bek.);

- a Vodafone-ügyben meg kell állapítani, hogy a különadó nem rendelkezik a héa harmadik és a negyedik jellemzöjével, nevezetesen azzal, hogy sor kerülhetne az adónak a termelési és forgalmazási folyamat minden egyes szakaszában történő felszámítására, továbbá az e folyamat előző szakaszában megfizetett adó levonására (63. bek.).

Fától az erdőt...

Mindkét ítéletben feltủnő az, hogy az EUB - Juliane Kokott fötanácsnok indítványát követve ${ }^{27}$ - azért nem látja a közvetett hátrányos megkülönböztetés lehetöségét, mert az a megfelelő piacon ,,esetleges, söt véletlenszerü”, hogy éppen a más tagállambeli vállalkozások magyarországi leányvállalatait sújtja az adó (Vodafoneítélet, 52. bek., fötanácsnoki indítvány ugyanezen ügyben, 81. bek.). E naivnak tetsző érvelést Magyarországon mindenki megmosolyogja. Világosan lehetett ugyanis tudni - ahogy az összes többi ágazati különadó esetében -, hogy a kormány a más tagállamból származó tőkeerős vállalkozásokat célozza meg az adóval, miközben a gyengébben ellátott hazai vállalkozásokat adminisztratív eszközökkel előnyben kívánja részesíteni.

Csak féligazság, hogy a különadóról szóló 2010-es törvény elfogadása során az elsődleges hangsúly a multinacionális vállalatokra irányult (főtanácsnoki indítvány, 96. bek.), legalább ennyire fontos, ha nem fontosabb ugyanis az a törvényhozói szándék, pontosabban a mögötte álló kormánypropaganda, hogy úgymond a kis-

${ }^{27}$ Lásd a C-75/18. Vodafone sz. ügyben 2019. június 13-án ismertetett indítványát, EU:C:2019:492. A C-323/18. Tesco sz. ügyben a fötanácsnok ugyancsak Juliane Kokott volt. Az ez utóbbi ügyben ismertetett álláspont érdemét tekintve azonos a Vodafone-ügyben kifejtettekkel, kivéve a harmonizált hét-rendszerrel való összevethetőség kérdését, amellyel azonban csak érintőlegesen foglalkozik. 
embereket védjék meg a 2008-as globális pénzügyi válság kezelésével összefüggő adóterhektől, szemben a korábbi szocialista kormányokkal, amelyek állítólag éppen az egyszerü magyar polgárokra hárították a válság terheit. Érdemes ezzel összefüggésben felidézni, hogy a magyar kormány ismét készül megadóztatni a másik tagállamból származó nagyvállalatokat, helyettesítendő a 2013-ban kivezetett bolti kiskereskedelmi adót, miután felbátorodott az EUB sorozatos döntésein. Az új adó a régivel megegyező módon az árbevételt terheli meredeken emelkedő progresszív adómértékkel, de most már a törvényjavaslat címében is szerepelnek célpontként „,a nagybevételü cégek”.

A beterjesztett törvényjavaslathoz a kormány a következő magyarázatot füzte: „,[a] magyar adózási modell változatlan, az emberek, a kisvállalatok továbbra is kevés adót fizetnek. A cél az, hogy az egyensúlyjavitó adóintézkedések terhét ne a lakosság, hanem azon szereplök viseljék, amelyek erre képesek, amelyek a járványt megelözö időszakban kiemelkedö nyereségre, jelentös piaci fölényre tettek szert."28 Ebből kitűnik, hogy a magyar adópolitika változatlan, vagyis a már kivezetett válságadók (ágazati különadók) egyenes folytatásáról van szó, ráadásul az adóalap öszszeszámítására vonatkozó szabályt is ismét bevezetik, csak most az adózó számára kimentési lehetőséget biztosítanak. ${ }^{29}$

Úgy tűnik, a főtanácsnok nem látja a fától az erdőt, és a jogi precizitás elérésének igyekezetében hoz döntést, miközben a valós tagállami helyzet ettől nagyon különbözhet, azt nem is említve, hogy a fötanácsnok arra hivatkozik, hogy a kormány nyilatkozatai nem számítanak, mert a kormány a parlament döntéséhez van kötve, nem pedig fordítva (98. bek.), miközben köztudott, hogy a magyar parlamenti történéseket a kormány, közelebbről a miniszterelnök határozza meg, még ha ez jogilag nem támasztható is alá. ${ }^{30}$ Azzal a visszatérő problémával is szembesülünk ugyanakkor, hogy az uniós jogvita eldöntésekor sok tekintetben nem állnak rendelkezésre olyan eszközök, amelyek révén a valós gazdasági-politikai helyzetnek megfelelő döntéseket lehetne hozni. A jog egyértelműséget kíván meg, ezért olyan praktikákat, mint amilyeneket a nyilvánvalóan célzott ágazati különadóak esetében

28 „A kormány benyújtotta a nagybevételű cégeket terhelő kiskereskedelmi különadóról szóló törvényjavaslatot“ (2020. április 28). Forrás: https://www.kormany.hu/hu/nemzetgazdasagi-miniszterium/adougyekert-felelos-allamtitkarsag/hirek/a-kormany-benyujtotta-a-nagybevetelu-cegeket-terhelo-kiskereskedelmi-kulonadorol-szolo-torvenyjavaslatot).

29 2020. évi XLV. törvény a kiskereskedelmi adóról, 5. § (5) bekezdés.

30 Sajnálatos, hogy az EUB és a főtanácsnok is döntések sorozatában figyelmen kívül hagyta a jogalkotás politikai hátterét, és így nem is juthatott plauzibilis következtetésre, állapítja meg az irodalom. Lásd: Szudoczky \& Károlyi (2020:66). 
is megfigyelhetünk, aligha lehet leleplezni, ilyen értelemben pedig a burokban lévő főtanácsnok sem hibáztatható.

Közvetett adókat a letelepedési szabadsággal nehéz összefüggésbe hozni (Spies, 2017:107), azok ugyanis termékek (és szolgáltatások) értékesítésére vonatkoznak, a letelepedési szabadság viszont nem az áruk, hanem a személyek szabad mozgásával hozható kapcsolatba. A közvetett adóknak jellemző módon területi hatályuk van, így határon átnyúló helyzetben általában nem merülnek fel közvetett adózási kérdések, az alapvető uniós szabadságok viszont csak határon átnyúló helyzetekre vonatkoznak. A közvetlen adók sokkal inkább érintettek a letelepedési szabadság kérdésében. Éppen a közvetett adók területi hatályára való hivatkozással lehet úgy érvelni, hogy minden tagállam szuverén módon maga állapítja meg például a héa esetében az alanyi adómentesség értékhatárát. ${ }^{31}$

A főtanácsnok egzakt jogi kritériumokat keres, a belső piac mozgása és az uniós szabadságok természete, ezekkel összefüggésben pedig a hátrányos megkülönböztetés tekintetében azonban ilyeneket gyakorlatilag lehetetlen felállítani. Az uniós jog hatvanéves története éppen arról szól, hogy az alapvető szabadságok korlátozása és ehhez kapcsolódva a hátrányos megkülönböztetés kérdésében a bevezetett jogintézmények gazdasági hatását kell felmérni, és ebből kell kiindulni a döntéshozatalkor. Ha ez nem így történt volna, akkor nem indulhatott volna be a Cassis de Dijon ${ }^{32}$ típusú ítélkezési gyakorlat, amely a belső piac 1993-as hatályba lépésével összefüggésben elvezetett az ekvivalenciaelv megjelenéséhez (a tagállami hatóságok gyakorlatait formális egyezség hiányában is egymáshoz kell igazítani, ha ennek hiánya az alapvető szabadságok gyakorlásának gátja lenne).

A fötanácsnok szerint a magyar ágazati különadó (konkrétan a távközlési adó) esetében felismerhető az árbevétel és a pénzügyi teljesítőképesség közötti közvetett kapcsolat (121. bek.), amiből az is következik, hogy közvetlen kapcsolat viszont nem ismerhető fel. A fötanácsnok szerint az eltérő bánásmód tekintetében nem döntő, hogy a progresszív adókulcsokat nyereség- vagy árbevétel-alapú adókra alkalmazzák-e. Ezt persze indokolni is kell, aminek során a fötanácsnok meglehetősen nyakatekert érvelést hoz elö: szerinte ugyanis még a nyereség és a fizetőképesség közötti kapcsolat is sokszor csak esetleges, az árbevétel viszont sokkal kisebb mértékben befolyásolható a számviteli elszámolás megválasztásának módjával (122. bek.).

${ }^{31}$ C-97/09. Ingrid Schmelz kontra Finanzamt Waldviertel, ECLI:EU:C:2010:632. 71. bek.

32 120/78. Rewe-Zentral AG kontra Bundesmonopolverwaltung für Branntwein, ECLI:EU:C:1979:42. 
E tekintetben megint kiütközik a fötanácsnok formalista látásmódja, figyelmen kívül hagyva azt, hogy például a veszteségelhatárolás korántsem fiktív módon csökkenti egy vállalkozás nyereségét. A számítási tétel például veszteségelhatárolás esetén egyáltalán nem fikció, hanem a vállalkozás valós jövedelmezőségének kimutatását segíti elő. A befektetések üzleti ciklusa ugyanis rendesen hosszabb egy évnél, adminisztratív okokból azonban a vállalkozásoknak évente beszámolót kell készíteniük és adóbevallást kell tenniük. A veszteségelhatárolás hasznos korrekció, mert a valós üzleti ciklus elszámolásához közelítő eredmény elérését teszi lehetővé, amivel szemben - gazdasági szempontból - éppen az éves számviteli elszámolás fikció.

A megítélendő tagállami intézkedés - jelen esetben egy ágazati különadó - jogi formájára vagy gazdasági kihatására összpontosítva egészen eltérő eredményre juthatunk. Ennek lettek az érintett magyar vállalkozások áldozatai a helyi iparüzési adó esetén is, amikor annak vizsgálata során az EUB mereven ragaszkodott a levonhatósági kritérium olyan értelmezéséhez, amely a hatodik forgalmiadó-irányelv szerkezetéhez igazodik, jóllehet az első irányelv szerint a harmonizált héa lényege csupán az adó fogyasztóra való átháríthatósága, ami viszont többféle jogilag értékelhető formában megvalósulhat. Kétségtelen, hogy a hatodik irányelv szerinti dokumentációhoz igazodva minden egyes ügyletnél fel kell tüntetni az értékesítés nettó értékét, majd az ahhoz kapcsolt adó összegét, amely a vevő számára levonhatóvá válik, míg például a helyi iparüzési adónál a hozzáadott érték kiszámítása az ügyletek időszakonkénti összesítésén alapul, de elvileg aggregált értékek alapján ugyanolyan pontosan meg lehet állapítani a hozzáadott értéket, mint ügyletenként. ${ }^{33} \mathrm{Ha}$ a jogi formalizmus lett volna jellemző a Cassis de Dijon-típusú ítéletekre, akkor soha nem lett volna lehetőség a versenytorzító tagállami intézkedések kimutatására.

\section{Adóhatósági eljárási jogok, a dohányipari egészségügyi hozzájárulás és az élelmiszerlánc-felügyeleti díj felfüggesztése}

Az ágazati különadók - amelyek jellemző módon árbevételre kivetett progreszszív adók - felvetnek eljárási kérdéseket is. Ilyenek az adóbejelentkezés, a bírságolás és az adófelfüggesztés. Mivel e témák adott uniós jogi vitában ágazati különadókat

${ }_{33}$ C-283/06. Vodafone, C-312/06 Kögáz sz. egyesített ügyek, ECLI:EU:C:2007:598. 40. és 50. bek. Az első forgalmiadó-irányelv 2. cikke tartalmazza: a bevezetendő adó az áruk és szolgáltatások értékesítésére általános érvénnyel kiterjed, az árbevétellel arányos és csak a hozzáadott értékre terjed ki, továbbá minden értékesítési fázist érint. Lásd: Tanács 67/227/EGK irányelve, HL 71. (1967.04.14.) 1301. o. 
érintenek, a teljesség kedvéért röviden tárgyaljuk a hivatkozott jogesetek kapcsán felmerült eljárási jogi problémákat, amelyekkel azonban érdemben nem foglalkozunk, tekintettel arra, hogy a jelen dolgozat kifejtése az ágazati adók anyagi jogi vetületére összpontosul.

A Google-ügy irataiból kitűnően a 2017. január 16-i határozatában az adóhatóság egyrészt megállapította, hogy a Google Ireland a reklámadóról szóló törvény hatálya alá tartozó tevékenységet folytat, másrészt pedig hogy a tevékenysége megkezdését követő 15 napon belül nem jelentkezett be az adóhatóságnál, megsértve ezzel a vonatkozó törvény megfelelő előírásait. Az adózó egyrészt vitatja azt, hogy a bejelentkezési kötelezettség kirovása a másik tagállamban letelepedett reklámszolgáltatókra összeegyeztethető lenne a szolgáltatásnyújtás szabadságával, a belföldön letelepedett reklámszolgáltatók esetében ugyanis ilyen kötelezettség nem áll fenn. Másrészt sérelmezi a kiszabott bírságok összegét és azt, hogy a hatóság nem biztosított az adózói kötelezettségek teljesítéséhez elégséges időt, miközben belföldi szolgáltatók esetén a bírság alacsonyabb, és hosszabb határidőt is élvezhetnek kötelezettségeik teljesítésére.

Az adózó továbbá azt is kifogásolja, hogy a nem Magyarországon letelepedett reklámszolgáltatók jogorvoslati lehetősége korlátozott, ami sérti egyrészt a hatásos jogorvoslathoz, másrészt a tisztességes eljáráshoz való jogot is. Az adózó hivatkozik e tekintetben az EUMSZ diszkriminációtilalmat kimondó 18. cikkére és az EU Alapjogi Chartájának ${ }^{34} 47$. cikkére. Az EUB az adózó első kérdése tekintetében nem állapította meg a szolgáltatási szabadság megsértését, a második kérdésben azonban igen.

A Bizottság a dohányipari egészségügyi hozzájárulás és az élelmiszerlánc-felügyeleti díj felfüggesztése tárgyában 2016. július 4-én két határozatot fogadott el, amelyekben megállapította, hogy a vitatott tagállami intézkedések jogellenesek, és Magyarországot a szóban forgó adóintézkedések végrehajtásának felfüggesztésére kötelezte. A tagállam 2015. szeptember 25-én keresetet nyújtott be a vitatott határozatok ellen annyiban, amennyiben azok elrendelik a dohányipari egészségügyi hozzájárulás és az élelmiszerlánc-felügyeleti díj felfüggesztését. A Törvényszék e kereseteket 2018. április 25 -én elutasította. ${ }^{35}$

A Bíróság 2020. június 4-én meghozott ítéletével megfordította a Törvényszék itéletét a vitatott adónemek felfüggesztése tekintetében, nem foglalkozva egyébként

${ }^{34}$ HL C 202. 2016.06.07. 389. o.

35 T-554/15., T-555/15. Bizottság kontra Magyarország sz. egyesített ügyek, ECLI:EU:T:2018:220. 
a vitatott adónemek jogellenességének kérdésével. ${ }^{36}$ A Bizottság úgy véli, hogy e határozatokat megfelelően indokolta, jelezve, hogy a támogatási intézkedések a bejelentésük előtt hatályba léptek. Mivel a Bíróság megítélése szerint a Törvényszék új indokokkal egészítette ki a Bizottság által kifejtett indokokat, és így túllépte hatáskörének korlátait, a Bíróság hatályon kívül helyezte a Törvényszék megtámadott ítéletét, és helyt adott Magyarország keresetének (72-73., 75. bek.).

\section{Tanulság: növekvő uniós szkepticizmus}

Valami megváltozhatott a jogpolitikai légkörben, amelyet kutatni ma még elégséges információ birtokában aligha lehet. ${ }^{37}$ Legfeljebb, ha összehasonlítunk egymással az EUB elé kerülö különböző ügyeket, akkor azt állapíthatjuk meg, hogy mintha korábban több olyan döntés született volna, amely az uniós harmonizációt mozdítja elő, igazat adva a kérelmező vállalkozásnak, amelyik kifogásolta tagállami intézkedéseknek az alapvető szabadságok némelyikét korlátozó intézkedéseit. Az EUB a C-75/18. Vodafone sz. és a C-323/18. Tesco sz. ügyekben 2020. március 3-án ellentmondott a Bizottság korábban kikezdhetetlennek látszó és egyébként szakmailag nagyon meggyőző álláspontjának. A Törvényszék a T-836/16., T-624/17. Bizottság kontra Lengyel Köztársaság sz. egyesített ügyekben már 2019. május 16-án szembeszállt a Bizottság jól kidolgozott véleményével.

Nem mellékes körülmény, hogy az EUB a C-456/18. P. Bizottság kontra Magyarország sz. ügyben 2020. június 4-én ugyan jogerősen jóváhagyta Magyarország keresetét a dohányipari egészségügyi hozzájárulás és az élelmiszerlánc-felügyeleti díj felfüggesztése tárgyában meghozott bizottsági határozatokkal szemben, de a tagállam eleve nem vitatta a Bizottságnak azt az álláspontját, hogy az adónemek érdemben nem összeegyeztethetők az uniós joggal. Ehhez képest az érintett tagállamokat is meglephette a Törvényszéknek a lengyel kiskereskedelmi adó ügyében meghozott ítélete. Még furcsább, hogy Juliane Kokott főtanácsnok a C-385/12. Hervis sz. ügyben még úgy érvelt: a magyar bolti kiskereskedelmi adóról esetleg megállapítható az, hogy az nem összeegyeztethető a harmonizált hozzáadottérték-adózás

36 C-456/18. P. Magyarország kontra Európai Bizottság sz. ügy, ECLI: EU:C:2020:421.

37 Aggodalomra ad okot az integráció barátainak például az, hogy a Német Szövetségi Alkotmánybíróság nemrég (2020. május 5-én) nyíltan szembement az EUB ítéleteivel, arra hivatkozva, hogy a tagállamok az elsődleges uniós jogot alkotó nemzetközi szerződések urai, és nem adtak feltétlen felhatalmazást uniós hatóságoknak (BVerfG, 2 BvR 859/15). 
rendjével, ${ }^{38}$ feltéve hogy a bírósági gyakorlatban kikristályosodott négy kritérium (az adó átháríthatósága, az adókivetés minden értékesítési fázisra való kiterjedése, általános alkalmazhatóság, az adó árral arányos megállapíthatósága) közül az első kettőt elhagyjuk. Ekkor inkább a gazdasági hatásra, mintsem a jogi formára összpontosítunk (miközben a fötanácsnok indítványa 104. bekezdésében Christine StixHackl főtanácsnok korábbi ügyekben kifejtett álláspontjára hivatkozik, amelyre a gazdasági hatásnak a jogi formával szembeni elsőbbségének a kifejezése a jellemző).

A Hervis-ügyben a fötanácsnok nem tartja kizártnak, hogy a bolti kiskereskedelmi adó összeegyeztethetetlen a harmonizált héa-rendszerrel. A Vodafone-ügyben viszont már egyértelmüen arra a következtetésre jut, hogy a távközlési adót ugyan az árbevétellel arányosan vetik ki, de átháríthatósága a fogyasztóra az adóteher utólagos kiszámítására vonatkozó szabály miatt nem áll fenn, ezért a levonhatóság nem biztosított (33. bek.), és nem is általános érvényü az adó (32. bek.), az ugyanis csak a távközlési szolgáltatások nyújtására terjed ki. Az EUB a Hervis-ügyben követett álláspontja alapján ugyanezen adóra vonatkozóan a Tesco-ügyben sem lenne kizárt foglalkozni a harmonizált hozzáadottérték-adóval való összeegyeztethetőség problémájával, csakhogy ott az előterjesztő nemzeti bíróság a kérdést előterjesztésében nem tette fel (és ezért az EUB sem vizsgálta). Más kérdés, hogy a fötanácsnok már a Hervis-ügyben is amellett foglalt állást, hogy a magyar adó nem összeegyeztethetetlen a letelepedési szabadsággal, és ezért nem is diszkriminatív (103. bek.).

A főtanácsnok ugyanannak a bolti kiskereskedelmi adónak a héa szempontjából való megítélése tekintetében nem következetes. A Hervis-ügyben a fötanácsnok úgy véli, hogy a vizsgált magyar adót nem vetik ki az értékesítés minden egyes fázisában, továbbá nem biztosított az adó levonhatósága sem (91. bek.). Fontos megállapítása az is, hogy az előzetesen felszámított adó levonása nem tartozhat a forgalmi adó alapvető jellemzöihez (104. bek.), továbbá a minden értékesítési szakaszban történő adókivetés sem minősül a forgalmi adó alapvető jellemzőjének (106. bek.). Rendelkezik viszont a magyar adó az árral arányos megállapítás alapvető jellemzőjével (111. bek.), az adókivetés általánosságát illetően pedig a fötanácsnok a magyar adót vizsgálva elégséges információ hiányában nem tud állást foglalni (117. bek.).

Ehhez képest a fötanácsnok a Tesco-ügyben azt állapítja meg ugyanazon bolti kiskereskedelmi adóval kapcsolatban, hogy a héa felől nézve az összevethetőség tekintetében nem teljesül az, hogy az adót általános érvénnyel vetnék ki, hogy az árral arányosan állapítanák meg, és hogy levonható lenne (29-30. bek.), arról a kritéri-

${ }^{38}$ L. a C-385/12. Hervis sz. ügyben 2013. szeptember 5-én ismertetett indítványt, ECLI:EU:C:2013:531, 125. bek. 
umról pedig nem nyilatkozik nemlegesen, hogy az adót az értékesítés minden egyes szakaszában kivetik. Ez teljesen ellentétes a Hervis-ügyben kifejtett álláspontjával, hiszen ott az árral arányos kivetés szerinte megvalósul, viszont az a feltétel nem, hogy az adót minden értékesítési fázisban kivetnék. További meglepetés, hogy míg a Hervis-ügyben a forgalmi adónak minősítés mellett érvel, a Tesco-ügyben viszont már azt fejtegeti, hogy a bolti kiskereskedelmi adó közvetlen adó (33. bek.). Ugyanezt állapítja meg egyébként a reklámadóval kapcsolatban is. ${ }^{39}$

Az világos a tárgyalt ágazati különadók esetében, hogy az adókötelezettség az árbevétellel arányos. A fogyasztóra való átháríthatóság kérdése viszont valóban vitatható, és elfogadható, hogy az áthárítás esetleges. Az áthárítás hiányára mégsem lehet olyan egyszerüen hivatkozni, mert nem tagadható: a kiskereskedelemben vásárlók számolhatnak azzal, hogy az árbevételre kivetett adó a szolgáltatás, ill. termék árát növelö tényező. Mivel pedig nem lehetséges azt állítani, hogy az árnövelö tényező kizárt lenne, a közvetlen adóként való minősítés messze nem látszik megalapozottnak.

\section{További tanulságok}

Az állami támogatások ellenőrzésének joga nyilvánvalóan a tág értelemben vett versenyjog része. Tiltott állami támogatás megvalósulhat adójogi eszközökkel is. Ilyenkor az uniós hatóságok ugyan adókat vizsgálnak, ezek azonban nem adójogi megítélés alá esnek. Az eljáró uniós hatóságok azt kívánják felderíteni, hogy vajon a vizsgált tagállami adóintézkedések versenytorzító hatást váltanak-e ki.

Az adójog mint szakjogág uniós jogi közegben amúgy is csak korlátozottan juthat érvényre. A tőkemozgások globális porondján a szakjogágak háttérbe szorulnak. Ez történt például az elmúlt évtizedekben a társasági joggal.

A nemzeti társasági jogi szabályozás kezd kiüresedni, mivel sok tekintetben a tőkepiac adminisztratív természetü akadályozó tényezőjének bizonyul. A nemzeti adórendszerek konvergenciája hiányában a társasági anyagi jogi szabályok leegyszerüsítésére, ugyanakkor a társaságok irányításával összefüggő jogok nemzetközi összehangolására van szükség. A háttérbe szoruló nemzeti társasági jog helyét inkább más ágazati korlátozások veszik át, amelyek nem a vállalkozás jogi típusához, hanem nagyságához igazodnak, és árbevételhez, alkalmazotti személyzethez vagy más szemponthoz kötött küszöböket alkalmaznak.

${ }^{39}$ Lásd: a C-482/18. Google sz. ügyben 2019. szeptember 12-én előterjesztett indítványt, ECLI:EU:C:2019:728, 32-33. bek. 
Ilyenkor a beavatkozás mennyiségi kritériumok alapján történik, a fö kérdés ugyanis az, hogy az a személy, aki tőkét képes gyüjteni, mennyire ellenőrizhető a kisbefektetők érdekeinek védelmére tekintettel, a veszély pedig a vállalati méretek növekedésével arányosan nő. Ezért bizonyos árbevételi vagy egyéb küszöbök felett szakhatósági engedélyeztetési eljárásokra kerülhet sor, vagy például elszámolások szabályozására, rendszerszintü kockázatot hordozó pénzügyi tranzakciók és a túlfütött tőkemozgások adminisztratív korlátozására, stb.

Az adójogi szabályozás terén a globális tőkepiaci mozgások megkívánják többek között az adójogi konszolidáció kiterjesztését akár a határon átnyúló tőkemozgások esetében is (lásd például a CCCTB esetét), ${ }^{40}$ leértékelve egyúttal például a hagyományos ügyleti alapú transzferár-megállapítási módszereket. A pénzügyi piaci hiperaktivitás megfékezésében alkalmazható adójogi eszköz többek között az IMF által már 2010-ben javasolt pénzügyi stabilitási hozzájárulás kivetése a pénzügyi vállalkozásokra (ez az ún. „,bank levy”). ${ }^{41}$ Hasonlóképpen sor kerülhet pénzügyi tranzakciós adó bevezetésére tagállami vagy uniós keretekben. ${ }^{42}$

Ezekben az esetekben az adójogi szempontok alárendelődnek a globális piacokról érkező tőke érdekeinek. A pénzügyi aktivitás hütése a tőkepiaci tevékenység folyamatos hatósági felügyeletét igényli, közben pedig a szabályozókat folytonosan módosítani kell a változó piaci helyzethez igazodva. A pénzügyi teljesítóképesség vagy piaci megítélés felmérésekor gyakori a becslés alkalmazása, ami nyilvánvalóan ellehetetleníti az adójogban kulcsfontosságú jogbiztonság szempontjának érvényesítését.

A versenyjog globálisan mér, mert a hatósági beavatkozás egyetlen mércéje a globális gazdasági hatás, ami a jogi értékelés lehetőségét sokszor minimalizálja. Állandó a vita például az állami támogatások vizsgálatakor abban, hogy a referenciakeretet miként kell megvonni a szelektivitást megállapítandó. Versenyjogi szempontból ennek igen szélesnek kell lennie, ami adójogi szempontból sokszor elfogadhatatlannak tűnik.

A versenyszabadság ugyan közérdek, de a versenygazdaság szereplői profitmaximalizáló magánszemélyek. Ilyen értelemben a versenyjog a globális tőke megjele-

${ }^{40}$ Proposal for a Council Directive on a Common Corporate Tax Base, Strasbourg, 25.10.2016 COM(2016), 685 final (first step - common tax base); Proposal for a Council Directive on a Common Consolidated Corporate Tax Base (CCCTB), Strasbourg, 25.10.2016, COM(2016) 683 final (second step - unitary taxation).

${ }^{41}$ A fair and substantial contribution by the financial sector, IMF final report for the G-20, June 2010.

${ }^{42}$ Proposal for a Council Directive implementing enhanced cooperation in the area of financial transaction tax, Brussels, 14.2.2013 COM(2013) 71 final. 
nésének következménye, amivel szemben a nemzeti szakjogokat érvényesíteni kívánó hatóságok a közérdek védelmében látszanak fellépni, nem megkerülhető mégis az ellentmondás, hogy a nemzetállam által védett közérdek lokális, a versenyszabadság előtt álló adminisztratív akadályok lebontásában érdekelt tőke viszont globális. Csak esetről esetre lehetséges állást foglalni abban, hogy a lokális közérdek vagy a globális magánérdek érdemel-e elsőbbséget.

Versenyjogi szempontból például összevethető egymással konszolidált és nem konszolidált vállalat, ami adójogi nézőpontból nem elfogadható. Ezért van az, hogy a Bizottság mint versenyhatóság számára logikus a forgalmi adó referenciakeretét úgy alakítani, hogy adottnak vesz egy egykulcsos, vagyis arányos adózást kivételt nem engedő szabályozással, amivel kapcsolatban a jogász mégis könnyen úgy találja, hogy fikció. Ha utóbbi igaz, akkor - de csak akkor - az adóprogresszivitás akár árbevételre kivetített adózás esetében is egy referenciakereten belül helyezhető el.

A kérdés tehát úgy vetődik fel, hogy a szakjogász meddig mehet el megfontolásainak érvényesítésében, ellenállva a globális befolyásolásnak. A versenyjogon keresztül a globális tőke üzen, amelynek nyomása alatt a nemzetállami jogi eszköztár sokszor elégtelen. Esetről esetre egyensúlyt kellene találni a szabad tőkemozgás és a nemzetállami szuverenitás között, de az inga sokszor túllendül hol ebbe, hol abba az irányba. Az árbevételre kivetett progresszív adók esetében úgy tủnik, a nemzetállami szuverenitás védelmezői nyerésre állnak az európai tőkepiacok további megnyitásának és a vonatkozó szabályozás harmonizálásának híveivel szemben.

\section{Hivatkozások}

Aquinas, T. (1920). The Summa Theologice of St. Thomas Aquinas. 2nd ed. (Translated by fathers of the English Dominican Province). Kevin Knight (ed.). Online edition, 2017. http.//www.newadvent. org/summa/.

Aristotle (2009). The Nichomachean ethics. Oxford University Press, New York.

Baumol, W. J. (1972). On taxation and the control of externalities. The American Economic Review, $62(3)$.

Ehlermann, C.-D. \& Goyette, M. (2006). The interface between EU state aid control and the WTO disciplines on subsidies. European State Aid Law Quarterly, 5(4).

HMRC (2015). Guidance on the Diverted Profits Tax, 30 November.

Kukovec, D. (2016). Economic law, inequality, and hidden hierarchies on the EU internal market. Michigan Journal of International Law, 38(1).

Nicolaides, P. (2019). Multi-rate turnover taxes and state aid. A prelude to taxes on company size? European State Aid Law Quarterly, 18(3).

OECD (2013). Action Plan on Base Erosion and Profit Shifting, OECD Publishing.

http://dx.doi.org/10.1787/9789264202719-en 
Rossi-Maccanico, P. (2004). State aid review of Member States' measures relating to direct business taxation. European State Aid Law Quarterly, 3(2).

Rossi-Maccanico, P. (2013). EU review of direct tax measures. Interplay between fundamental freedoms and state aid control. EC Tax Review, 22(1).

Smit, D. S. (2016). International juridical double non-taxation and state aid. EC Tax Review, 25(2).

Spies, K. (2017). Fundamental freedoms and VAT: an analysis based on the Credit Lyonnais case. World Journal of VAT / GST Law, 6(2).

Szudoczky, R. \& Károlyi, B. (2020). The troubled story of the Hungarian advertisement tax: how (not) to design a progressive turnover tax. Intertax, 48(1). 
MELLÉKLET

\begin{tabular}{|c|c|c|c|c|}
\hline Tárgy & Elsőfokú döntés & Időpont & Fellebbezés & Másodfokú döntés \\
\hline Kiskereskedelmi adó & $\begin{array}{l}\text { T-836/16., T-624/17. } \\
\text { Bizottság kontra } \\
\text { Lengyel Köztársaság } \\
\text { sz. egyesített ügyek }\end{array}$ & 2019. május 16. & $\begin{array}{l}\text { Igen, a } \\
\text { Bizottság }\end{array}$ & $\begin{array}{l}\text { C-562/19. P. (még } \\
\text { nincs döntés) }\end{array}$ \\
\hline Reklámadó & $\begin{array}{l}\text { T-20/17. Bizottság } \\
\text { kontra Magyarország }\end{array}$ & 2019. június 27. & $\begin{array}{l}\text { Igen, a } \\
\text { Bizottság }\end{array}$ & $\begin{array}{l}\text { C-596/19. P. (még } \\
\text { nincs döntés) }\end{array}$ \\
\hline Távközlési adó & C-75/18. Vodafone & $\begin{array}{l}\text { Nagytanács } \\
\text { 2020. március } 3 .\end{array}$ & - & - \\
\hline $\begin{array}{l}\text { Bolti kiskereskedel- } \\
\text { mi adó }\end{array}$ & C-323/18. Tesco & $\begin{array}{l}\text { Nagytanács } \\
\text { 2020. március } 3 .\end{array}$ & - & - \\
\hline $\begin{array}{l}\text { Adóhatósági eljárási } \\
\text { jogok (reklámadó) }\end{array}$ & C-428/18. Google & $\begin{array}{l}\text { Nagytanács } \\
\text { 2020. március } 3 .\end{array}$ & - & - \\
\hline $\begin{array}{l}\text { A dohányipari egész- } \\
\text { ségügyi hozzájárulás } \\
\text { és az élelmiszer- } \\
\text { lánc-felügyeleti díj } \\
\text { felfüggesztése }\end{array}$ & $\begin{array}{l}\text { T-554/15., T-555/15. } \\
\text { Bizottság kontra } \\
\text { Magyarország sz. } \\
\text { egyesített ügyek }\end{array}$ & $\begin{array}{l}\text { 2018. április } 25 . \text {, } \\
\text { 2020. június } 4 \text {. }\end{array}$ & $\begin{array}{l}\text { Igen, } \\
\text { Magyaror- } \\
\text { szág }\end{array}$ & $\begin{array}{l}\text { C- 456/18. P. } \\
\text { (jogerös) }\end{array}$ \\
\hline
\end{tabular}

